\title{
Ascending pathways mediating cardiovascular signals to the ventral posterior lateral nucleus of thalamus in the cat
}

\author{
Kazuko NODA, Hisanao AKITA, Masanori OGATA \\ and Sadao AIKAWA \\ Laboratory of Physiology, School of Allied Health Sciences,
Kitasato University
}

Abstract

Neuronal activities in the ventral posterior lateral nucleus (VPL) of the cat thalamus were recorded extracellularly using the multimicroelectrode system. In spontaneous activities, some neurons received information from structures related to cardiovascular movement and also from peripheral somatic receptive fields (Rfs). These unitary activities were synchronized with heart beat, therefore they are called as heart beat (HB) discharges. This phenomenon may be concerned with referred pain. Thus, some VPL neurons appear to relay cardiovascular information to the cerebral cortex. The characteristics of 39 HB units were determined by mechanical stimulation such as bending hair, tapping, pinching and joint movement. To investigate the ascending pathways, transection of vagi and partial spinal cord lesions at the cervical level were performed. HB activities were unaffected by bilateral vagotomy. Some of the HB activities disappeared following partial cordotomy of the lateral portion of the ventrolateral funiculus ipsilateral to the receptive field. However, evoked responses to electrical stimulation applied to the HB Rfs persisted. After the remaining cord was severed, the evoked responses vanished. These results show that afferent signals of HB activities and evoked responses to electrical stimulation appear to ascend through different pathways and converge at the thalamic level.

Key words: Thalamic VPL, Referred sensation, Cardiovascular input, Somatosensory input, Ascending pathways

\section{Introduction}

Convergence of somatosensory and visceral inputs had been reported at the spinal $\operatorname{cord}^{1.5}$, medulla oblongata ${ }^{6)}$, thalamus ${ }^{7-9)}$ and cerebral cortex $^{10)}$. On the other hand, cardiac referred pain projected on the body surface such as the hyperalgesic zone had been attributed to the viscero-somatic reflex or convergence of sensory inputs onto the spinal cord ${ }^{11}$. Blair et al.,12) reported the spinal cord cells in C8-T5 segments that project to the ventral posterior lateral nucleus (VPL) of thalamus were responded to intracardiac injection of bradykinin with the increased activity. After injection, this activity became synchronized with the cardiac cycle ${ }^{4,12,13)}$. Foreman et al., 5) applied antidromic stimulation to the thalamic ventrobasal complex and demonstrated that afferent information from cutaneous and visceral structures converged onto the spinothalamic cells of the spinal cord

correspondence to: Kazuko Noda, Laboratory of Physiology, School of Allied Health Sciences, Kitasato University, 1-15-1 Kitasato, Sagamihara, Kanagawa 228-8555 Japan Tel. \& Fax : +81-427-78-8153 
and projected to the VPL neurons.

Aikawa et al. ${ }^{14)}$ originally recorded neuronal activities recorded in the thalamic VPL synchronized with heart beat (HB) extracellularly and most of these thalamic HB units have also somatic receptive fields (Rfs). They observed that $\mathrm{HB}$ discharges were intermingled with the socalled spontaneous discharges by a time series analysis of spontaneous activities ${ }^{14}$. The Rfs of these $\mathrm{HB}$ units were widely distributed contralateral to the recording site not only near the area associated with referred pain in heart disease but also from head to tail ${ }^{15}$. These phenomena indicated the convergence and interference of afferents originating from superficial and visceral structure on the thalamic neurons, and also suggested the relationship between the visceral organ and the distant acupuncture points.

The HB discharges disappeared after intravenous injection of a hypolethal overdose of sodium pentobarbital but evoked discharges did not, which suggesting the difference of their ascending pathways ${ }^{15,16)}$. However, the ascending pathway of the HB impulses remains unclear.

As described in the preceding paper ${ }^{16}$, $\mathrm{HB}$ unitary discharges have been divided into three types based on the characteristics of discharge patterns in the post $\mathrm{R}$-wave time histograms (PRTHs) such as unimodal-, bimodal-, and multimodal-HB units. The present study attempts to clarify the ascending pathways of the convergent input of cardiovascular and somatic information of unimodal-HB units.

\section{Methods}

The experiments were carried out on 38 adult cats weighing $2.3-4.5 \mathrm{~kg}$. Animals were anesthetized with sodium pentobarbital (30-35 mg/kg, i.p.). A cephalic vein was cannulated in order to infuse fluids. The animals were immobilized with pancuronium bromide $(0.3 \mathrm{mg} / \mathrm{kg} / \mathrm{h}$, i.v.). Trachea was cannulated and artificially ventilated. Arterial blood pressure and ECG were recorded throughout the experimental period.

Extracellular recordings were made from the VPL neurons using the multimicroelectrode system $^{17)}$ that consisted of four $\mathrm{Pt}-\mathrm{Co}$ microelectrodes. The multimicroelectrodes were inserted through the intact cortex to the thalamus ${ }^{18)}$ using the modified "closed head" technique ${ }^{19}$. To discriminate the HB discharges, so called spontaneous discharges were analyzed by generating post R-wave time histograms (PRTHs) triggered by the R-wave of ECG. Recordings of unitary discharges were amplified and continuously monitored on an oscilloscope, stored on magnetic tape and analyzed on- and offline using a medical computer (ATAC-450, Nihon Kohden) for constructing PRTHs.

The response characteristics and Rfs of units were determined using mechanical stimulation such as bending hair with an air-puff or with a small brush, tapping the skin and pressing with a small rod, pinching the skin with forceps and joint movement.

To identify the ascending pathways which carry HB and somatosensory signals, bilateral vagotomy and spinal lesions at the cervical level (C3-C5) were performed. First, a dorsal column lesion was performed with a scalpel and a dorsal quadrant ipsilateral to the Rf was severed 3-4 $\mathrm{mm}$ rostral to the first lesion. Then, hemisection ipsilateral and contralateral to the $\mathrm{Rf}$ was performed successively rostral to the prior sectioning. Electrical stimuli were applied to the Rf before and after sectioning through a pair of stainless steel needles ( $\Phi 0.30 \mathrm{~mm}, 25 \mathrm{~mm}$ ) inserted into the skin and/or muscle. Stimulation consisted of rectangular pulses of $0.1 \mathrm{~ms}$ in duration with at twice the response threshold triggered by R-wave of ECG.

The recording sites were marked by passing direct current through the recording 
microelectrodes. At the end of the experiment, the animals were sacrificed by an overdose intravenous injection of sodium pentobarbital and perfused with physiological saline followed by $10 \%$ formalin. The brain and cervical spinal cord were removed and placed in formalin. After at least one week, the brain was frozen and cut into serial $40 \mu \mathrm{m}$ thick slices with a freezing microtome and stained with cresyl violet.

Spinal cord blocks containing lesions were embedded in paraffin, serially sectioned in $10 \mu \mathrm{m}$ thick slices with a microtome and stained with cresyl violet. Recording sites and extension of spinal lesion were verified histologically.

Results

1) Characteristics of $\mathrm{HB}$ units

The present results are based on a sample of 39 thalamic HB units recorded in the VPL region. Since the cordotomy was performed at the cervical level, the results from the HB units having Rfs on the head area were not included. All units recorded had spontaneous activities. The PRTH analysis was performed on every spontaneous neuronal activity to discriminate the $\mathrm{HB}$ discharges. In addition to searching for $\mathrm{HB}$ units, we recorded non-HB units simultaneously.

Figure 1A shows examples of HB unit and non$\mathrm{HB}$ unit recorded simultaneously using the multimicroelectrode technique. It is difficult to simply discriminate $\mathrm{HB}$ discharges from spontaneous discharge sequences by observing the original spike traces. In the PRTHs, HB discharges are observed with a constant latency of $188 \mathrm{~ms}$ from ECG R-wave (relative latency) (Fig. 1B).

Classification of the response properties of the VPL neurons has been described previously, ${ }^{9}$. HB units were divided into three categories; lowthreshold mechanoreceptive (LTM) units, which

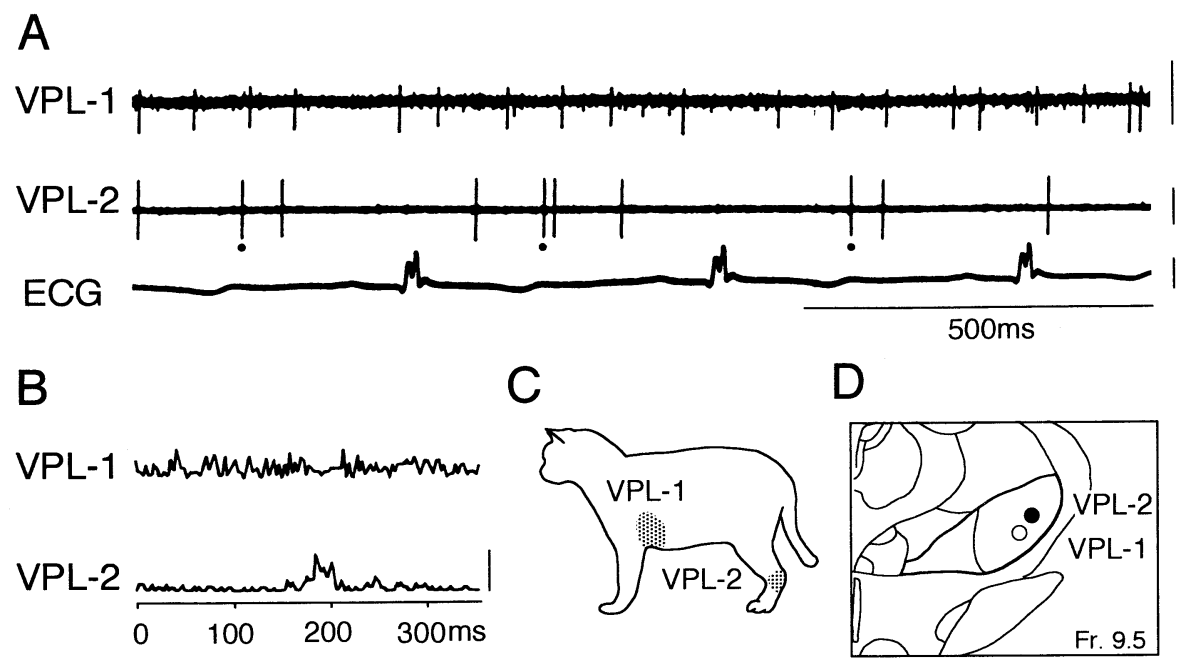

Fig. 1 Examples of $\mathrm{HB}$ and non-HB units simultaneously recorded by multimicroelectrodes

A : upper two traces (VPL-1 and 2) show spontaneous discharges; bottom trace shows ECG. HB unitary discharges are difficult to distinguish from original traces. Small dots indicate HB discharges. Vertical bar : $0.5 \mathrm{mV}$. B : post- R-wave time histograms (PRTHs). HB discharges with a peak latency of $188 \mathrm{~ms}$ from R-wave are observed unit VPL-2. Each PRTH represents average of 50 heart beats. Analysis time $: 358.4 \mathrm{~ms}$. Bin width : 2.8ms. Vertical bar : 10 spikes. $\mathrm{C}:$ each $\mathrm{Rf}$ is indicated by a shaded area. D : Location of each cell in right thalamic VPL. $:$ HB unit, $\bigcirc$ : non-HB unit. Area enclosed by a solid line indicates VPL and VPM. Abbreviation: VPL ; ventral posterior lateral nucleus, VPM ; ventral posterior medial nucleus. 


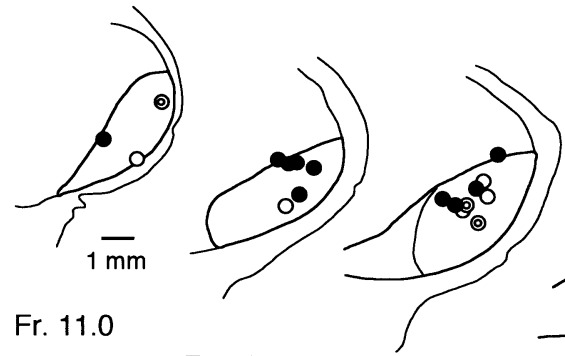

Fr. 10.5

○ LTM

Fr. 10.0

๑ WDR

- DP

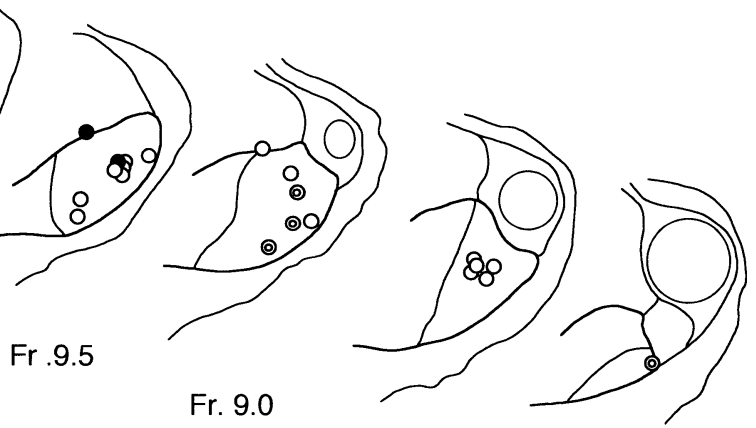

Fr. 8.5

Fr. 8.0

Fig.2 Location of recording sites for HB units determined from electrolytic lesions

Cells were plotted according to response characteristics. Symbols used are shown in insets. Numbers in bottom row of each thalamic cross-section indicate anteroposterior level of that section modified from Jasper and Ajmone-Marsan's atlas ${ }^{18}$. Most rostral section is shown at left. Recording sites from same anteroposterior level were placed on same section.

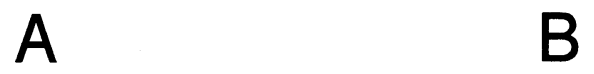

\section{Control}
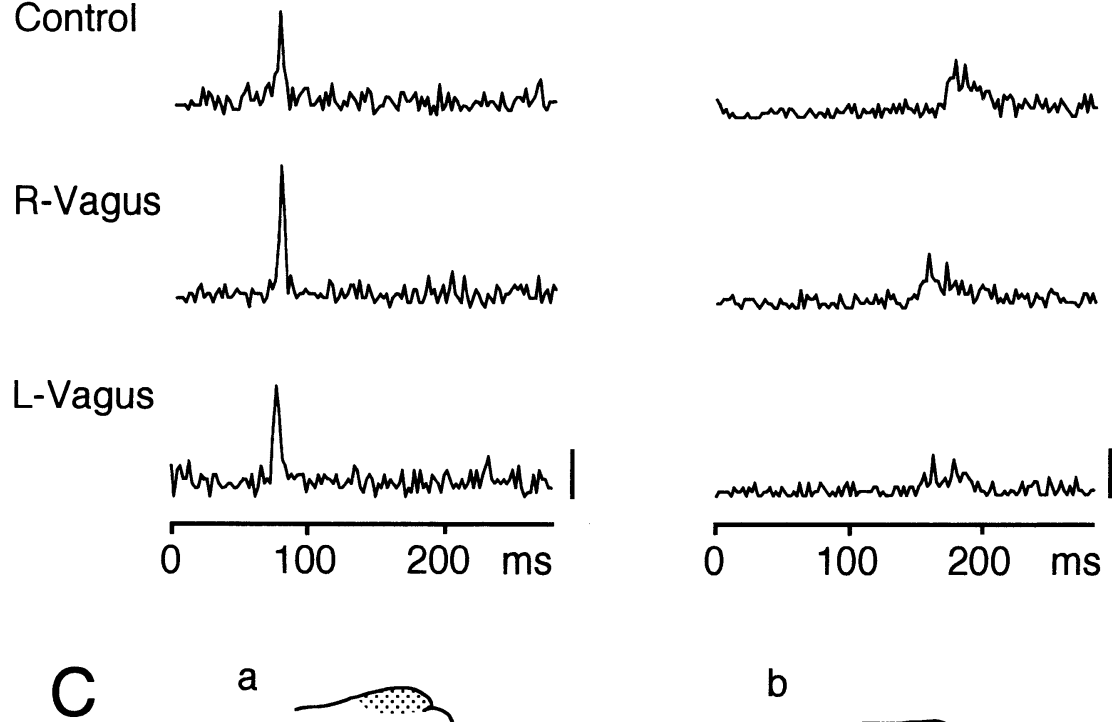

a

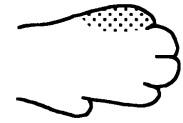

b

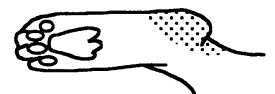

Fig.3 Effect of bilateral vagotomy at cervical level on HB units

$\mathrm{A}$ and $\mathrm{B}:$ PRTHs before and after vagotomy. R-Vagus : after right vagotomy. L-Vagus : after left vagotomy. Each PRTH represents average of 50 heart beats. Analysis time : $281.6 \mathrm{~ms}$. Bin width $: 2.2 \mathrm{~ms}$. Vertical bar : 10 spikes. C : each Rf is indicated by a shaded area. 
responded to innocuous cutaneous stimulation (bending hair and tapping); wide dynamic range (WDR) units, which responded to both innocuous and noxious cutaneous stimulation (pinching); and deep (DP) units, which responded to pressing and/or joint movement. The number of units belonging to the LTM, WDR and DP classes was 20, 7 and 12, respectively. Nociceptive specific (SN) neuron ${ }^{9)}$ was not observed in this study. To determine the receptive field of NS neuron, it is necessary to apply strong mechanical stimulation to the skin surface that left some damage to the skin of animals. We made an effort to keep the damage minimal.

\section{2) Location of recording sites for HB neurons}

The recording sites of $39 \mathrm{HB}$ units recorded are plotted in Figure 2. DP units tended to locate in the rostral VPL region, whereas LTM units tended to be frequently found in the caudal region. WDR units were widely distributed rostro-caudally. The modalities of the cells tended to alter DP to LTM when the electrodes were inserted from the dorsal to the ventral VPL.

\section{3) Effects of vagotomy}

Bilateral vagotomy was performed at the cervical level (Fig. 3). Following bilateral vagotomy, the relative peak latency of the $\mathrm{HB}$ activities remained unchanged (Fig. 3A). Figure $3 \mathrm{~B}$ shows an example in which the relative peak latency of the HB discharges was shortened slightly following vagotomy. The peak latency of HB activities on the PRTHs prior to vagotomy was $174 \mathrm{~ms}$. Following right vagotomy, the latency was shortened to $157 \mathrm{~ms}$ (Fig. 3B). The effects of vagotomy were examined on $23 \mathrm{HB}$ units. In the 19 units, the relative latency of the $\mathrm{HB}$ activities remained unchanged following bilateral vagotomy (Fig. 3A). In the other 4 units the relative peak latency in the PRTHs were shortened after vagotomy (Fig. 3B).

\section{4) Effects of cordotomy}

Spinal lesions at the cervical level were performed on VPL units simultaneously recorded. Figure 4 shows the response of VPL units to peripheral electrical stimulation before and after selective lesions to the spinal cord. Unit VPL-1 was a HB unit with the relative peak latency of HB discharge at $57 \mathrm{~ms}$ and unit VPL-2 was a non-HB unit. Following spinal cord lesion to the dorsal horn using a scalpel, HB activities of unit VPL-1 persisted. The evoked responses of both units persisted even after a part of the spinal cord was severed (Fig. 4 Lesion 1). The HB discharges disappeared after the dorsolateral funiculus (DLF) and ventrolateral funiculus (VLF) ipsilateral to the Rfs were severed whereas the peripheral inputs to unit VPL-1 were persisted (Fig. 4 Lesion 2). The peripheral inputs to unit VPL-1 disappeared after the region contralateral to the Rfs was severed (Fig. 4 Lesion 3). Input to unit VPL-2 disappeared after the remaining cord was sectioned (Fig. 4 Lesion 4). Thus, the afferents from the Rfs and the HB signals to the thalamic units ascend through different pathways, respectively.

The effects of spinal lesion on the HB discharges and the somatosensory evoked discharges of 19 units are summarized in Table 1. In 11 of the 19 units, both HB and peripheral evoked discharges vanished after the same spinal lesion. In 8 units, HB activities and impulses from the periphery ascended through a different region of the cervical cord. The response characteristics of these 8 units consisted of 4 LTM and 4 WDR cells. In the DP units, the ascending pathways did not differ between the HB and peripheral inputs at the cervical level.

These results suggest that a proportion of the HB activities may ascend through the dorsal or ventral part of spinal cord ipsilateral to the Rfs and converge with somatosensory input onto the VPL. 
A

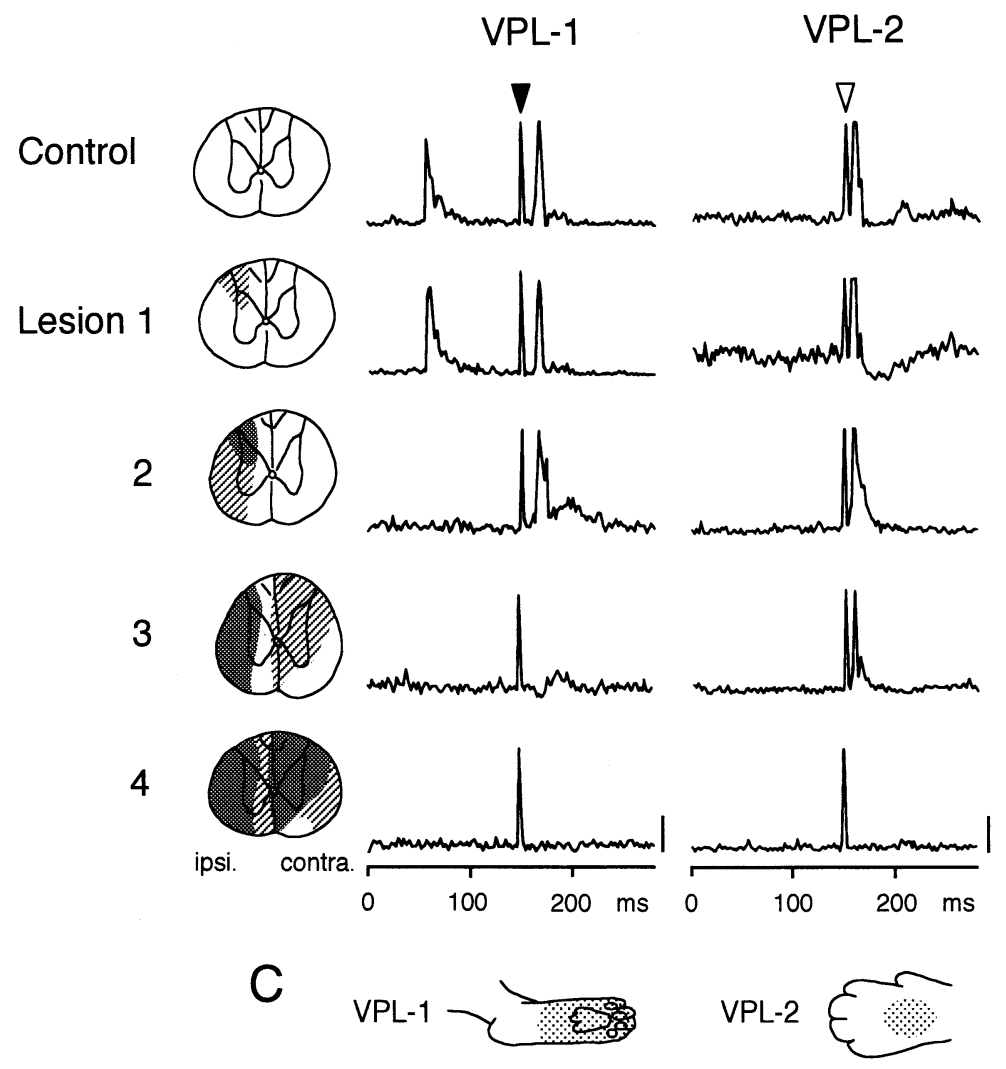

Fig.4 Effects of cordotomy at cervical level

Units in B (VPL-1 and 2) are recorded simultaneously. Tracing in VPL-1 is for HB unit. That in VPL-2 is for non-HB unit. A : shaded areas indicate successive spinal lesions at cervical level (C4) made prior to histogram. Darkened area indicate previous lesion. ipsi : ipsilateral to Rf. contra : contralateral to Rf. B : PRTHs of spontaneous discharges and electrically evoked discharges. Triangles represent stimulus artifact. Each PRTH represents average of 50 heart beats. Analysis time : $281.6 \mathrm{~ms}$. Bin width : $2.2 \mathrm{~ms}$. Vertical bar : 20 spikes. C : each Rf is indicated by a shaded area.

Table 1 Site of cordotomy of which HB and electrical evoked discharges disappeared

\begin{tabular}{lcccc}
\hline \hline $\begin{array}{l}\text { lesion site of } \\
\text { cervical spinal cord }\end{array}$ & DC & $\begin{array}{l}\text { disappearance of evoked discharges } \\
\text { ipsi. DLF-VLF }\end{array}$ & contra. DLF-VLF & total \\
\hline $\begin{array}{l}\text { disappearance of } \\
\text { HB discharges }\end{array}$ & & & 1 & 7 \\
\multicolumn{1}{c}{ DC } & 4 & 2 & 2 & 7 \\
ipsi. DLF-VLF & 0 & 5 & $3 *$ & 5 \\
contra. DLF-VLF & 1 & 1 & 6 & 19 \\
\hline total & 5 & 8 & & \\
\hline
\end{tabular}

Cordotomy was performed at C3-C5. DC; dorsal column. ipsi. DLF-VLF; dorsolateralventrolateral funiculus ipsilateral to Rf. contra. DLF-VLF; dorsolateral-ventrolateral funiculus contralateral to $\mathrm{Rf} .{ }^{*}$; HB and electrical evoked discharges of 1 out of 3 cells disappeared after different spinal lesion within site contralateral to $\mathrm{Rf}$. 


\section{Discussion}

The present results demonstrate that some VPL neurons respond not only to somatic inputs but also discharge synchronous with the cardiac cycle. Synchronization between neuronal activity and arterial pulsation has been previously reported in peripheral nerves ${ }^{21-23)}$, spinal cord ${ }^{4,24,25)}$, dorsal column nuclei ${ }^{26)}$, thalamus ${ }^{14-16)}$ and cerebral cortex ${ }^{27}$. Yamamoto et al. ${ }^{26)}$ recorded activity synchronized with arterial pulsation in the dorsal column nuclei. Downman and Evans ${ }^{24)}$ also recorded action potential synchronous with the end of systole at the thoracic level (T4). Furthermore, Mountcastle and Powell ${ }^{27)}$ reported synchronous impulses with arterial pulse recorded from single cortical neurons. They considered this phenomenon to relatively high level representations of cardiovascular events in the central nervous system. Intracardiac injection of bradykinin is a powerful activator of cardiac sympathetic afferents and these afferents mediate cardiac pain $^{12,13}$. Blair et al. ${ }^{4,12)}$ reported the spinal cord cells that projected to the VPL responded to intracardiac injections of bradykinin with the increased activity. After injection, this activity became synchronized with the cardiac cycle ${ }^{4,122}$. The HB unit may participate in mechanism of referred pain.

Synchronization of neuronal activity with the cardiac cycle during application of bradykinin has been attributed to the ability of bradykinin to sensitize sympathetic afferents to mechanical events $^{12}$. Gebber et al. ${ }^{23)}$ reported a relationship between heart beat rhythm and the neuronal network at the level of the medulla oblongata with respect to the nervous control of cardiovascular function. According to their report, the afferents from the baroceptors of the heart and surrounding structures pass through sympathetic nerves and the inputs activate or inhibit the brain stem neurons, resulting in the appearance of $2-6 \mathrm{~Hz}$ rhythm ${ }^{23}$ including cardiac cycle.

If vagal afferents mediate the $\mathrm{HB}$ activities on VPL neurons, one might expect that the responses to vagal stimulation would be observed and/or that the HB discharges would be affected by vagotomy. In the present study, vagal stimulation did not induce a response in the $\mathrm{HB}$ units. The peak latency of some HB discharges were shortened only slightly following bilateral vagotomy (Fig. 3). The HB discharges appear to be little related to vagal afferents.

Pain arising from visceral or deep structures tend to refer to an area of superficial structures. The central nervous mechanisms associated with cardiac pain remain unclear ${ }^{12,13}$. Several theories have been proposed to explain the phenomenon of referred pain, especially pain associated with angina pectoris which can be sensed over a wide area of the thorax ${ }^{1128,29}$. The convergenceprojection theory presented by Ruch ${ }^{11}$ is considered to be the most likely theory to explain referred pain ${ }^{13}$. This theory suggests that visceral and somatic afferent information excites the same cells of the spinothalamic tract (STT) ${ }^{11}$.

In the present study, cardiovascular information ascended through the ventrolateral quadrant ipsilateral to the $\mathrm{Rf}$ in 7 (36.8\%) of 19 $\mathrm{HB}$ cells (Table 1.). In the cat, only $40 \%$ of the ventrolateral tract fibers are crossed ${ }^{30}$. Furthermore, Pomeran $z^{30}$ found that the $\mathrm{A} \delta$ and $\mathrm{C}$ fibers from the skin which converge onto the interneurons in the gray matter of the cord, and the axon of this neuron turns into the ipsilateral white matter and projects to the brain.

The HB impulses passed through the dorsal portion of the cord in 7 (36.8\%) of $19 \mathrm{HB}$ units. Postsynaptic dorsal column (PSDC) and spinocervical tract (SCT) that ascends within the dorsal quadrant were also included in the painsignalling systems in the spinal cord. Recently, the dorsal column pathway has been proposed to 
play an important role in visceral nociception and relate to the referred pain ${ }^{31}$.

The upper cervical cord is likely to be an important somatosensory relay. Kenshalo et al. ${ }^{32}$ reported that some thalamic neurons receive convergent input from the dorsal column-medial lemniscus system and from ventral quadrant pathways. Pomeranz ${ }^{30)}$ also reported that 86 of 128 fibers that ascend ipsilaterally through the ventrolateral quadrant responded to noxious stimulation as well as light touch and thermal stimuli. Ma et al. ${ }^{33)}$ reported the medial lemniscal from dorsal column nuclei and STT from spinal cord sometimes contact to single ventrobasal neuron of rat and thus converge at the thalamic level.

Many neurons of the STT and spinoreticular tract (SRT) are located in the upper cervical cord. More specifically, Yezierski ${ }^{34)}$ suggested that nociceptive information from the heart may converge on spinomesencephalic tract (SMT) cells at the C1-C3 segment in cats. Sensory inputs to neurons in this region have been considered to project to the ipsilateral or contralateral thalamus ${ }^{35,36}$. Thus, information regarding cardiac events can be assumed to reach the spinal, reticular, and thalamic level ${ }^{12}$. Aikawa et al. $^{37}$ ) reported that HB activities were modulated by electrical stimulation applied to the receptive field. In the present study the ascending pathways of the spinal cord that convey cardiovascular and cutaneous information differed in $8 \mathrm{HB}$ units with superficial input. Some HB units may be related to deep inputs including pericardiac muscle tissues.

The present results suggest that sympathetic afferents mediate HB impulses, because bilateral cervical vagotomy failed to eliminate these $\mathrm{HB}$ activities. In addition, 8 (42.1\%) out of 19 units, the HB activities and evoked responses were confirmed to pass through different pathways at the cervical level. Thus, both inputs from the viscera and periphery may converge not only at the spinal cord, but also at the upper level of the central nervous system.

These observations may help explain the complicated central mechanisms involved in the medial lemniscal and extralemniscal systems ${ }^{38)}$ and may help explain the mediation of information associated with referred pain.

\section{Acknowledgment}

This work was supported in part by grants from the Ministry of Health and Welfare of Japan and from Kitasato University (Grant-in-Aid No. SAHS-C115-1994 and No. SAHS-C112-1995).

\section{References}

1) Pomeranz, B., Wall, P. D. and Weber, W. V.: Cord cells responding to fine myelinated afferents from viscera, muscle and skin. J. Physiol., 199: 511-532, 1968

2 ) Foreman, R. D.: Viscerosomatic convergence onto spinal neurons responding to afferent fibers located in the inferior cardiac nerve. Brain Res., 137: 164-168, 1977

3 ) Foreman, R. D. and Weber, R. N.: Responses from neurons of the primate spinothalamic tract to electrical stimulation of afferents from the cardiopulmonary region and somatic structures. Brain Res., 186: 463-468, 1980

4 ) Blair, R. W., Weber, R. N. and Foreman, R. D.: Responses of thoracic spinothalamic neurons to intracardiac injection of bradykinin in the monkey. Circ. Res., 51: 8394, 1982

5 ) Foreman, R. D., Blair, R. W. and Weber, R. N.: Viscerosomatic convergence onto T2-T4 spinoreticular, spinoreticular-spinothalamic and spinothalamic tract neurons in the cat. Exp. Neurol., 85: 597-619, 1984

6 ) Rigamonti, D. D. and Hancock, M. B.: Viscerosomatic convergence in the dorsal 
column nuclei of the cat. Exp. Neurol., 61: 337-348, 1978

7 ) McLeod, J. G.: The representation of the splanchnic afferent pathways in the thalamus of the cat. J. Physiol., 140: 462-478, 1958

8 ) Langenstain, H. and Rubin, F. J.: Representation of splanchnic afferents in the nucleus ventropostero-lateralis of the cat. Pflügers Arch., 31: 279-282, 1972

9 ) Taguchi, H., Masuda, H. and Yokota, T.: Cardiac sympathetic afferent input onto neurons in nucleus ventralis posterolateralis in cat thalamus. Brain Res. 436: 240-252, 1987

10) Korn, H.: Splanchnic projection to the orbital cortex of the cat. Brain Res., 16:23-38, 1969

11) Ruch, T. C.: Pathophysiology of pain. In: Fulton, J. (17th Ed.), A Textbook of Physiology, pp.350-368. W. B. Saunders Company, Philadelphia and London, 1955

12) Ammons, W. S., Girardot, M-N. and Foreman, R. D.: Effects of intracardiac bradykinin on T2-T5 medial spinothalamic cells. Am. J. Physiol., 249: R147-R152, 1985

13) Foreman, R. D.: Organization of the spinothalamic tract as a relay for cardiopulmonary sympathetic afferent fiber activity. Prog. Sens. Physiol., 9: 1-51, 1989

14) Aikawa, S., Ohta, K., Akita, H., Meguro, Y. and Kobayashi, S.: Referred sensation like phenomenon in thalamic VB-neurons. J. Physiol. Soc. Japan, 44: 374, 1982

15) Aikawa, S., Noda, K., Akita, H., Hotsumi, K., Ochiai, N. and Kobayashi, S.: Referred sensation like phenomenon and acupuncture effect in thalamic VB-neurons. Bull. SeisinIgaku Inst., 23: 103-111, 1984

16) Aikawa, S.: Characteristic properties of spontaneous discharges synchronized with heart beat in thalamic ventrobasal complex. J. Jap. Soci. Acu., 47 :214-230, 1997
17) Saburi, M., Niki, K., Kobayashi, S. and Aikawa, S.: A magnetically coupled multimicroelectrode system. IEEE Transactions Biomedical Engineering, BME30: 341-346, 1983

18) Jasper, H. H. and Ajmone-Marsan, C.: A stereotaxic atlas of the diencephalon of the cat. National Research Cauncil of Canada, Ottawa., 1954

19) Amassian, V. E., Berlin, L., Macy, J. Jr. and Waller, H. J.: Simultaneous recording of the activities of several individual cortical neurons. Trans. N.Y. Acad. Sci., 21: 395-405, 1959

20) Chung, J. M., Lee, K. H., Surmeier, D. J., Sorkin, L. S., Kim, J. and Willis W. D.: Response characteristics of neurons in the ventral posterior lateral nucleus of the monkey thalamus. J. Neurophysiol., 56: 370390, 1986

21) Whitteridge, D.: Afferent nerve fibres from the heart and lungs in the cervical vagus. J. Physiol., 107: 496-512, 1948

22) Uchida, Y., Kamisaka, K., Murao, S. and Ueda, H.: Mechanosensitivity of afferent cardiac sympathetic nerve fibers. Am. J. Physiol., 226: 1088-1093, 1974

23) Gebber, G. L.: Central oscillators responsible for sympathetic nerve discharge. Am. J. Physiol., 239: H143-H155, 1980

24) Downman, C. B. B. and Evans, M. H.: The distribution of splanchnic afferents in the spinal cord of cat. J. Physiol., 137: 66-79, 1957

25) Gebber, G. L. and McCall, R. B.: Identification and discharge patterns of spinal sympathetic interneurons. Am. J. Physiol., 231: 722-733, 1976

26) Yamamoto, S., Sugihara, S. and Kuru, M.: Microelectric studies on sensory afferents in the posterior funiculus of cat. Jpn. J. Physiol., 6 : 68-85, 1956

27) Mountcastle, V. B. and Powell, T. P.: Central nervous mechanisms subserving position 
sense and kinesthesis. Johns Hopk. Hosp. Bull., 105: 173-200, 1959

28) MacKenzie, J.: Some points bearing on the association of sensory disorders and visceral disease. Brain, 16: 321-354, 1893

29) Sinclair, D. C., Weddell, G. and Feindel, W. H.: Referred pain and associated phenomena. Brain, 71: 184-212, 1948

30) Pomeranz, B.: Specific nociceptive fibers projecting from spinal cord neurons to the brain: a possible pathway for pain. Brain Res., 50: 447-451,1973

31) Hirsberg, R. M., Al-Chaer, E. D., Lawand, N. B., Westlund, K. N. and Willis, W. D.: Is there a pathway in the posterior funiculus that signals visceral pain? Pain, 67: 219-305, 1996

32) Kenshalo, D. R., Giesler, G. J., Leonard, R. B. and Willis, W. D.: Responses of neurons in primate ventral posterior lateral nucleus to noxious stimuli. J. Neurophysiol., 43: 15941614,1980

33) Ma, W., Peschanski, M. and Ralston, H. J. III.: The differential synaptic organization of the spinal and lemniscal projections to the ventrobasal complex of the rat thalamus. Evidence for convergence of the two systems upon single thalamic neurons. Neuroscience, 22: 925-934, 1987

34) Yezierski, R. P. and Broton, J. G.: Functional properties of spinomesencephalic tract (SMT) cells in the upper cervical spinal cord of the cat. Pain, 45: 187-196, 1991

35) Carstens, E. and Trevino, D. L.: Anatomical and physiological properties on ipsilaterally projecting spinothalamic neurons in the second cervical segment of the cat's spinal cord. J. Comp. Neurol., 182: 167-184, 1978

36) Hodge, C. J., Apkarian, A. V., Gingold, S. and Stevens, R. T.: Spinothalamic tract cells of the high cervical spinal cord of primate. Pain, 40: 98, 1990

37) Aikawa, S., Noda, K., Akita, H., Iwashita, Y. and Kobayashi, S.: Interferences in visceral afferent inputs and somatic signals induced by electric stimulation for body surface. J. Physiol. Soc. Japan, 45: 438, 1983

38) Bowsher, D. and Albe-Fessard, D.: The anatomophysiological basis of somatosensory discrimination. Int. Rev. Neurobiol., 8: 35-75, 1965 


\title{
ネコ視床後外側腹側核ニューロンへの心血管系信号の上行性伝導路
}

\author{
野田和子 秋田久直 緒形雅則 相川貞男 \\ 北里大学医療衛生学部生理学研究室
}

\begin{abstract}
要 旨
ネコ視床後外側腹側核（VPL）より細胞外導出したユニットの自発発火の中には心拍動に同期する （HB）発火の混在するものがあり、その多くが体表末梢受容野を有する。この連関感覚様現象の解析の ためHBユニットの体表入力と心血管系入力の上行性伝導路について検討した。両側の䅡部迷走神経切 除を行ったが HB 発火は消失しなかった。頝髄レベルでの春髄部分切除結果より心血管系入力の一部は 当該受容野に対して同側の前側索外側部を経由し VPL ニューロンに投射するが、体表入力とは異なる 脊髄内伝導路を上行することが明らかになった。心血管系情報および体表末梢受容野よりの求心性信号 は脊髄レベルに加え視床レベルにおいても収束していることが確認された。
\end{abstract}

キーワード：視床VPL、連関感覚、心血管系情報、体性感覚情報、上行性伝導路 